\title{
Ideology, Change \& Power in Literature And Society: A Critical Discourse Analysis of Literary Translations
}

\author{
Nader Assadi Aidinlou \\ Department of English Language, Islamic Azad University, Ahar Branch, Ahar, Iran \\ E-mail: naderasadi@yahoo.com \\ Hamid Nezhad Dehghan \\ Department of English Language, Islamic Azad University, Ahar Branch, Ahar, Iran \\ E-mail: bndehghan@yahoo.com
}

Majid Khorsand (Corresponding Author)

Department of English, East Azarbaijan Science and Research Branch, Islamic Azad University, Tabriz, Iran

E-mail: khorsand.majid@gmail.com

Received: 05-06-2014

Accepted: 05-08-2014

Published: 01-11-2014

doi:10.7575/aiac.ijalel.v.3n.6p.260

URL: http://dx.doi.org/10.7575/aiac.ijalel.v.3n.6p.260

\begin{abstract}
The main purpose of this paper is to assess the translation quality of a political literary text, i.e. Orwell's Animal Farm, from the viewpoint of critical discourse analysis (CDA) and explore the degree to which ideology and power relations play major roles in the two Persian translations. Adopting the CDA framework of Van Dijk under Lefevere's notion of ideology, change and power in literature and society, this paper examined two different English-Persian translations of an excerpt from Animal Farm, The Seven Commandments, to pinpoint the interwoven relation between ideology, change and power and translation. To discover the impact of these phenomena on each other, a detailed contrastive/comparative study at the micro/macro-level in terms of fore/back-grounding mechanisms was conducted to examine, describe and subsequently interpret the patterns in the source text (ST) and its target texts (TTs). The findings of the study illuminated that too significant ideological distortions and manipulation were made in the translations to consider them as adequate translations.
\end{abstract}

Keywords: Critical Discourse Analysis (CDA), Ideology, Power, Literary Translation, Translation Quality Assessment (TQA), The Seven Commandments

\section{Introduction}

Translation quality assessment is an approach that assists translators and translation researchers in pinpointing the quality of translated texts in order to enhance the quality of future translations especially with regard to literary translations. One of the dominant methods through which the quality of literary translations can be assessed is critical discourse analysis (CDA). Discourse Analysis (DA) is a discipline concerning the study of the relationship between language and the context in which it is used, that is, the study of language in use. Critical discourse analysis is used in translation research to illuminate to what extent translators' mind is influenced by ideological considerations, which are coded and manifested in the translated texts. Texts, as they stand in society are not neutral; they are ideologically loaded. It is claimed that "almost any decision in translation is consciously or unconsciously guided by ideological criteria" (Nord, 2003, p. 111). Thus, manipulation of ideology and power relations through translation is among the critical issues that should be taken into account in the process of translating. On the other hand, translation is the recontextualization of an original culture, ideology, language and text in a new social, cultural and linguistic context. The new context particularly in the case of translation of literary works like Orwell's Animal Farm is primarily a cultural and political field in which the text will fulfil functions and goals. The context in the translation might be quite different from the functions and goals it served in the original culture and context. Furthermore, this paper pinpoints the interwoven relation between critical discourse analysis and translation in literary works. In this study, manipulation is considered as a delicately ingenious strategy for influencing the minds of an audience or readership through the distortion and internalization of certain beliefs, values, attitudes, or ideologies (Van Dijk, 1998). This study highlights the relationship between language and ideology, uncovers the invisible underlying ideological assumptions in the texts, and discovers to what extent the translators' ideologies are imposed in their works. In this respect, Lefevere's notions of patron and patronage were included in order to prove the biased ideological approaches applied to the translations aiming at manipulating the poetics and ideology of the original. Moreover, manipulation is done to the benefit of a power or an agent's interest (Khorsand \& Salmani, 2014b, p. 135). Adopting the CDA framework of Van Dijk (1999), this paper examines two different English-Persian translations of an excerpt from Orwell's Animal Farm (1945), “The Seven Commandments", by Homayoun Noor-Ahmar (1983), as target text one (TT1), and Narges Heydari Manjili 
(2009), as target text two (TT2). On the basis of Van Dijk's CDA framework, certain sociocultural, sociopolitical and ideological constraints of the translator influence the translation of literary discourse. With regard to translation quality assessment and based on the qualitative method of analysis in this paper, an adequate translation is the one with less manipulation and distortions of the original ideology and power relations. In other words, the more manipulation and distortions of the original ideology and power relations the less adequate the translation is. This means that the amount of manipulation and distortions is the main yardstick of judging whether a translation is more or less adequate. To accomplish the objectives, this study strives to give an account of the ways in which ideology manifests itself in the lexical and grammatical choices made in the two Persian translations of the excerpt. An in-depth comparative and contrastive analysis is adopted at the micro/macro-level in terms of fore/back-grounding mechanisms to analyze, describe, and interpret the patterns in the original and its two translations. These mechanisms include lexicalization and dominant grammatical metaphors. To put it in a nutshell, this study is going to answer the following questions:

(a) What ideological motivations were embedded in the original version of The Seven Commandments?

(b) What original ideological motivations and themes have been distorted or manipulated in the Persian translations?

(c) What ideological motivations and considerations were embedded in the Persian translations of The Seven Commandments?

(d) To what extent were the power relations changed or distorted in the Persian translations?

(e) Which translation was translated more adequately from Lefevere's perspective through the CDA framework of Van Dijk?

\subsection{Background of the problem}

Language use and discourse are the "critical social practices influenced by ideologies", which in turn also influence "how we acquire, learn or change ideologies" (Van Dijk, 2003, p. 9). Discourse "plays a fundamental role in the daily expression and reproduction of ideologies" (p. 4). Accordingly, novel discourse is one of the ideology-teaching/learning channels. Orwell's Animal Farm (1945) has been one of the challenging and demanding literary texts in translation because of its rich ideological and sociopolitical themes. The seven principles of Animalism, known as the seven commandments in this novel were reduced to a single principle: "all animals are equal, but some animals are more equal than others" (Orwell, 1945, p. 63). This illuminates that these principles were so critical that have gone under such considerable ideological manipulation. Therefore, the investigation of the critical discourse analysis of these principles from ideological perspective is crucial. In fact, the cultural, sociopolitical and ideological constraint and considerations consciously or unconsciously lie behind each translator's decision-making.

\subsection{The Seven Commandments}

Orwell writes Animal Farm as the opposition to political oppression and totalitarianism of his time. The novel begins with a powerful incentive for animals to initiate a war against Jones, as the symbol of a man, under the inspiration of pigs as the leaders. Appearing at the arrival of the story, Old Major is the most eminent trustworthy old experienced pig of the farm who tells the animals "his dream in the form of the song "Beasts of England" of unity among animals living together in peace without being tyrannized, oppressed, or controlled by human beings" (Khorsand \& Salmani, 2014a, p. 225). Old Major was "twelve years old and had lately grown rather stout, but he was still a majestic-looking pig, with a wise and benevolent appearance ... [He was so popular among the animals that] everyone was quite ready to lose an hour's sleep in order to hear what he had to say" (Orwell, 1945, p. 13). On the last days of his life, old Major called every animal to come together for a meeting to convey his message including his dream and the gist of his life experience as some seminal principles for animals. The three leading pigs- Napoleon, Snowball and Squealer- "had elaborated old Major's teachings into a complete system of thought, to which they gave the name of Animalism" (Orwell, 1945, p. 18). After the pigs changed the name of the farm from "MANOR FARM" to "ANIMAL FARM", Snowball and Napoleon explained that "by their studies of the past three months the pigs had succeeded in reducing the principles of Animalism [introduced by old Major] to Seven Commandments" as "an unalterable law by which all the animals on Animal Farm must live for ever after" (p. 21):

\section{The Seven Commandments}

1. Whatever goes upon two legs is an enemy.

2. Whatever goes upon four legs, or has wings, is a friend.

3. No animal shall wear clothes.

4. No animal shall sleep in a bed.

5. No animal shall drink alcohol.

6. No animal shall kill any other animal.

7. All animals are equal.

It should be underlined that the commandments begin with clarifying and distinguishing an enemy from a friend. Then four rules come after and the commandments end in "All animals are equal". The sense of opposition to hypocrisy and 
duplicity is rampant in Animal Farm. In fact, the animals were easily exploited. In other words, they implicitly trusted the pigs and blindly accepted what they were told. There is an English quotation that says "true friends stab you in the front" (Wilde, n.d.). However, the pigs did exactly the opposite of this, that is, they stabbed the animals in the back. This means that they exploited the animals' sincere trust insincerely.

The pigs inscribed the seven commandments in great white letters against the end wall of the big barn. Moreover, the expression "The Seven Commandments" was intelligibly chosen. Religion as one of the most powerful phenomena of the world has always taken the words seven and commandment [emphasis added] into special consideration: Seven Heavens (Quran); the Sabbath, as mentioned in Ten Commandments, i.e. Saturday or Sunday as the seventh day of the week specialized for rest and prayer (LDOCE, 2009); Ten Commandments of Moses on Mount Sinai. Moreover, other examples refer to the nature: Seven Seas (all the waters or oceans of the world) and Seven Continents (MerriamWebster, n.d.). It seems that Orwell tried to highlight that the pigs in Animal Farm as the political leaders of the farm take religion as a tool for controlling the animals since they truly believe in religion as the only true source of inspiration of animals and the major remote control for them as the public. However, The Seven Commandments changed or revised by the pigs usually under the pretext that most of the animals are not intelligent enough to learn them by heart. At the first step, Snowball cuts them to the single saying, "Four legs good, two legs bad" (Orwell, 1945, p. 25). Seizing an opportunity, the sheep chant this maxim at meetings. Later on, the principles changed into the revised and manipulated ones as follow:

No animal shall sleep in a bed with sheets. (p. 38)

No animal shall kill any other animal without cause. (p. 46)

No animal shall drink alcohol to excess. (p. 54)

ALL ANIMALS ARE EQUAL BUT SOME ANIMALS ARE MORE EQUAL THAN OTHERS. (p. 63)

The gradual distortions and manipulation of the Seven Commandments illuminate the endemic hypocrisy among the pigs as the leaders and their violence against the animals' logic, language, ideals and identity. Moreover, the changes in the commandments highlight the corruption of power which no animal could imagine at the beginning of the rebellion by the leadership of the pigs.

\subsection{Translation, Translators and Readers}

Translation has been defined by many scholars from different and sometimes contrary perspectives. Among them, Lefevere (2002, p. 1) believes in Petrus Danielus Huetius's definition of translation as "a text written in a well-known language which refers to, and represents a text in a language which is not as well known". This definition underlines the necessity of the representation of a foreign text in one's own culture through translation. Representation means (a) the action or fact of one person standing for another so as to have the rights and obligations of the person represented (b) the substitution of an individual or class in place of a person (Merriam-Webster, n.d.). Hence the original and its translation will discoursally function as the same intentions and purposes to their respective receptors. Accordingly, Lefevere (2002) sheds more light on translation:

Translation has to do with authority and legitimacy and, ultimately, with power, ... translation is a channel opened, often not without a certain reluctance, through which foreign influences can penetrate the native culture, challenge it, and even contribute to subverting it. (p. 1)

Translation is the rewriting of the original and it is "potentially the most influential because it is able to project the image of an author and/or a (series) of work(s) in another culture, lifting that author and/or those works beyond the boundaries of their culture of origin,..." (Lefevere, 1992, p. 9). Lefevere maintains that "Trust [enough to entrust the translators with the task of translating] may be more important than quality [in some cases]" (2002, p. 2). This means, the quality of translation is taken for granted or is considered in an inferior position when talking of trust. With respect to "trust" and "expertise", it can be claimed that "translators can be trusted more with texts that are not central to the culture as a whole since they can only do limited damage at worst. ... [This means that] different types of texts need to be translated in different ways" (p. 3). The proof for this is Orwell's Animal Farm which has been translated into Persian by almost fifteen translators in the last four decades. The more number of different translations out of one original text demonstrates the greater extent of liberties that translators are allowed mainly at the linguistic level. This can be a golden opportunity for translators to develop the knowledge of their own language:

If translators do try to represent a text that claims to represent the original in their culture, liberties on the purely linguistic level will be tolerated when they are seen as potentially refining, improving, extending the language of the receiving culture. In this case readers can judge for themselves since they are no longer judging the correspondence of original and translation but rather the wording of the translation which is, after all, written in their own language. (p. 4)

On the other hand, some scholars claim that translation is not carried out for the monolinguals who are not able to read and comprehend the original but for the educated readers who have the opportunity to compare and contrast the original and discover the linguistic, cultural and ideological differences and appreciate the poetics of the time in which the original is written in its own cultural discourse. In this respect, the main decision maker for displaying the features of 
the original culture and the link between translators and target readership is "patron" who selects the features and gives all the permission (Lefevere, 2002; see also Khorsand \& Salmani, 2014a). In fact, a patron deals with facts selectively with biased ideological approaches and circumscribes the power of the original and translator in order to manipulate the poetics and ideology of the original. In other words, the translator sacrifices the original for patronage. Regarding the issue of fidelity, Lefevere underlines that:

If a translator is bound, in general, to adhere with fidelity to the manners of the age and country to which his original belongs, ... he [or she] will find it necessary to make a slight sacrifice to the manners of his modern readers. (p. 134)

Lefevere (1992) stressed the terms "writings" (or original literary texts), "rewritings" (or translated literary texts), "writers" (or authors of original texts), and "rewriters" (or translators). Rewriting is "the motor force behind literary evolution, and the necessity for further in-depth study of the phenomenon" (p. 2). Regarding literary translations, he holds, "acceptance or rejection" and "canonization or non-canonization" of the works deal with the issue of "power, ideology, institution, and manipulation". Translators usually take a more active and special role in different positions in the process of translating:

Translators are rewriters of original literary texts. They usually occupy different positions at courts, in educational institutions, in publishing houses and in other institutions. Although some rewriters preserve ideologies, some of them manipulate original ideologies by elevating or combating or destroying them in favor of a power agency. (p. 7)

Furthermore, Lefevere (1992) proposes the expressions "canonized literary texts" or "high literature" and "noncanonized literary texts" or "low literature". The two categories refer to the works that take a central and peripheral position in the culture in question respectively. Moreover, "professional readers of literature" are differentiated from "non-professional readers of literature" in which the latter refer to "the majority of readers in contemporary societies" (p. 6). In fact, when they have read a book it means that "they have a certain image, [i.e.] a certain construct of that book in their heads. That construct is often loosely based on some selected passages of the actual text of the book in question". They "are exposed to literature more often by means of rewritings than by means of writings" (p. 7).

\subsection{Ideology, Power and Critical Discourse Analysis}

There have been different definitions of the term ideology through different perspectives. Plamenatz (1970, p.15) refers to ideology as "a set of closely related beliefs or ideas, or even attitudes, characteristic of a group or community." For Van Dijk (2003, p. 6), "ideologies have something to do with systems of ideas, and especially with the social, political or religious ideas shared by a social group or movement". Therefore, "as systems of ideas of social groups and movements" ideologies both "make sense in order to understand the world (from the point of view of the group)", and "as a basis for the social practices of group members" (p. 8). Widespread ideologies, for example "communism, anticommunism, socialism and liberalism, feminism and sexism, racism and antiracism, pacifism and militarism", are "more or less positive or negative depending on our point of view or group membership" (p. 6). Van Dijk underlines that "ideologies are the fundamental beliefs of a group and its members" (p. 7). Regarding the definitions of ideology, Mayr (2008) maintains that:

Definitions usually fall into two broad categories: a relativist definition, denoting systems of ideas, beliefs and practices, and a critical definition, allied with Marxist theory, which sees it as working in the interests of a social class and/or cultural group. When critical discourse analysts argue that discourse embodies ideological assumptions, they use the term ideology in a critical sense. (pp. 10-11)

Fairclough (1992, p. 87) claims that ideologies are "significations/constructions of reality (the physical world, social relations, social identities) which are built into various dimensions of the forms/meanings of discursive practices, and which contribute to the production, reproduction or transformation of relations of domination". To critical discourse analysts, ideologies are as "serving the interests of certain groups with social power, ensuring that events, practices and behaviors come to be regarded as legitimate and common-sense. Ideologies do this subtly, because they inform the way people interpret the world around them, hence hegemony" (Mayr, 2008, p. 11).

Fairclough (2001a) underlines that the focus of CDA is mainly on social concerns: "CDA analyzes texts and interactions, but it does not start from texts and interactions" (p. 26). He holds that "It starts rather from social issues and problems, problems which face people in their social lives, issues which are taken up within sociology, political science and/or cultural studies". Furthermore, Fairclough (1992, p. 10) argues that every instance of language use has three dimensions: it is a spoken or written language text; it is an interaction between people involving processes of producing and interpreting the text; and it is a piece of social practice. With regard to the main thrust in CDA, Mayr maintains that:

CDA therefore addresses broader social issues and attends to external factors, including ideology, power, inequality, etc. and draws on social and philosophical theory to analyze and interpret written and spoken texts. ... CDA researchers therefore typically examine how the microstructures of language are linked with and help to shape the macrostructures of society. $(2008$, p. 9)

\subsection{Ideology, Power and Translation}

Ideology has been defined differently ranging from the Marxist conception of false consciousness, Terry Eagleton's (1991) power/belief, to Van Dijk's (1996) systematized evaluative beliefs. Van Dijk's (1996) collective and shared 
beliefs are identical to Toury's (1999) norms. Nord (1991, p. 36) argues over the questions arising out of the translation practice from the power/ideology-oriented prospect:

What gets translated (what is valued and what is excluded)? Who does the translation (who controls the production of translation)? Who is translated for (who is given access to foreign materials and who denied)? How is the material translated (what is omitted, added, altered, to control the message)?

Moreover, with respect to the ideological manipulation in translation as well as other forms of communication, Eagleton (1991, p. 9) proposes the question "who is saying what to whom for what purposes". With regard to the multifarious relationship between ideology and translation, Schäffner (2003, p. 23) underlines that "any translation is ideological since the choice of a source text and the use to which the subsequent target is put is determined by the interests, aims, and objectives of social agents". Concerning the determined text-based ideological aspects, Schäffner highlights that these aspects can be "at the lexical level (reflected for example, in the deliberate use choice or avoidance of a particular word) and the grammatical level (for example, use of passive structures to avoid an expression of agency)". Explicitly identified as power relations, ideology is involved in every phase of human communication, and translation has been as one of essential communication channels particularly in the interlingual, intercultural, and sociopolitical realms. Accordingly, ideological manipulation plays an important role in this process. Therefore, translation has never been isolated form ideology. On the other hand, one of the dominant ideological tools for cognitive manipulation is literary translation. Lefevere (2002) believes that:

Translation is .... a rewriting of an original text. ... [reflecting] a certain ideology and a poetics and as such manipulate literature to function in a given society in a given way. Rewriting is manipulation, undertaken in the service of power, and in its positive aspect can help in the evolution of a literature and a society. . . The study of the manipulative processes of literature as exemplified by translation can help us towards a greater awareness of the world in which we live. (p. xi)

\section{Methodology}

The main purpose of this paper is the quality assessment of two Persian translations of the seven commandments from Orwell's Animal Farm. The assessment is done by the analysis of linguistic structures of both the original and its two Persian translations attributed to the fundamental function in the social production of ideology, power, and their manipulation. Thus the focus of the analysis is on exploring the original sociopolitical ideological themes and considerations and power relations embedded by the author and comparing and contrasting them with their translations. The result of this exploration sheds more light on the researchers' path to discover the distortions, changes and manipulation carried out in the translations. In other words, it is the in-depth linguistic analysis which aids the researchers in finding out the significant ideologies and power relations in the source text and their manipulation in the target texts. Taking ideology as a discursive phenomenon, in the qualitative phase of the investigation, the analysis is carried out in the following sequence: first the source text and the target texts are read and scrutinized. Second, the lexical and grammatical items in the translations are paired with the corresponding ones in the source text to find out the differences. Then the distortions and manipulation are discovered and interpreted in details. Under Lefevere's (2002) notion of ideology, change and power in literature and society, the focus of this paper is on the CDA framework of Van Dijk (1999), comparing and contrasting the source text and its two Persian target texts at the micro/macro-level in terms of fore/back-grounding mechanisms in order to examine, describe, and subsequently interpret the patterns.

\subsection{The mechanisms}

The significant attention in this study was on translation as the task of rewriting and translators intending to influence the target text readership through their adopted ideology (Lefevere, 2002). Therefore, certain choice of lexical items and syntactic metaphors that were used and applied by the translator would not be accidental but deliberate and ideological. Based on the CDA framework of Van Dijk (1999) at the micro-level, the mechanisms include (a) lexicalization, and (b) dominant grammatical metaphors.

\subsubsection{Lexicalization}

Lexicalization concerns the use of biased terms, certain concepts or ideologically-motivated expressions. Van Dijk (1998) claims that clarifying all implications of the words being used in a particular discourse and context often provides a comprehensive range of ideological meanings. The subcategories dealt with in this paper were as follows:

(a) Distorted lexical item. The items that have been distorted ideologically by the translator.

(b) Lexical variation. The variation in the items lexically with ideological intentions.

(c) Over-lexicalization. Over-lexicalization is "the availability of many words for one concept, and indicates the prominence of the concept in a community's beliefs and intellectual interests" (Fowler, 1991, p. 69). With regard to over-lexicalization, Fairclough (1992, p. 193) uses the expression "over-wording" to refer to the relative density of the number of words used to name the concepts from a particular domain, which may be "a sign of intense preoccupation, pointing to peculiarities in the ideology of the group responsible for it". In this article, over-lexicalization is the extensive and repeated use of certain lexical items as well as their loaded ideology in the target texts.

(d) Under-lexicalization. Under-lexicalization is the opposite tool to over-lexicalization referring to the phenomenon in which a lexical item that would precisely refer to a concept, is deliberately avoided, suppressed, or substituted for another one. 
(e) Euphemistic expressions/Euphemism. Similar to the phenomenon of under-lexicalization in the sense of avoidance of a lexical item, euphemism is "a word which is substituted for a more conventional or familiar one as a way of avoiding negative values" (Fairclough, 2001b, pp. 97-98).

(f) Addition vs. omission. When any lexical item is added or omitted, it is called addition and omission respectively. Any addition and omission in the translation lead to and stand for ideological manipulation.

\subsubsection{Dominant syntactic metaphors}

Dominant syntactic metaphors or dominant grammatical choices are powerful ideological tools including various strategies as a response to possible interlingual translation problems. The strategies dealt with in this paper were as follows:

(a) Transitivity (Passivization vs. Activization). Although not all verbs allow passivization to the same extent, it allows the writer or speaker to leave out the actor/experiencer/speaker in the sentence. That is, the real subject of the sentence is missed intentionally. It is a strategy to protect sources by omitting the performer/doer, or to retail their own opinions as if they were someone else's. In fact, passivization has no such inherent meaning. That is, meaning is all the time the outcome of a specific reader's inferential processing. Only the literal interpretation is allowed.

(b) Nominalization (vs. De-nominalization). Nominalization is "the grammatical process of forming nouns from other parts of speech, usually verbs or adjectives" (Richards \& Schmidt, 2002, p. 360). Nominalization makes the sentence more indirect and difficult to read. In other words, nominalization diminishes the strength of one's speech or prose. It can also remove context and cover any sense of agency. Moreover, it can make something that is unclear or uncertain seem stable, powered and precisely defined. Hitchings (NY times. Retrieved. 5/4/2013) claims that "nominalizations give priority to actions rather than to the people responsible for them" and "often they conceal power relationships and reduce our sense of what's truly involved in a transaction". As such, the newspaper continues that they are "an instrument of manipulation, in politics and in business" stressing on "products and results, rather than the processes by which products and results are achieved".

(c) Modalization/Modality. This refers to the status of the proposition that describes the event (Palmer, 2001). She holds that modalization is strictly related to tense (in relation with the time of the event) and aspect (in relation with the nature of the event) in that all three are categories of the clause (ibid). Modality is a resource that writers and speakers use when they are staking claims to knowledge: it allows them to formulate different kinds of claims (e.g., assertions, opinions, hypotheses, speculations) and indicate how committed they are to those claims (Cameron, 2007).

\section{Data Analysis}

As it was mentioned in the introduction, two translations of the excerpt "The Seven Commandments" (Orwell, 1945, p. 21) were analyzed discoursally. The translations were by (a) Homayoun Noor-Ahmar (1983, pp. 29-30), as target text one (TT1), and (b) Narges Heydari Manjili (2009, p. 29), as target text two (TT2). The analysis of the problematic sentences of the commandments appeared in this section along with their translations as well as the translations' IPAtranscription, transliteration and back-translation respectively. For the ease of reference and application, only the number of the commandments was given.

\subsection{Analysis and Discussion}

Title of the Commandments

\section{ST: THE SEVEN COMMANDMENTS}

IPA-transcription: /hæft færmpn/

Transliteration: seven commandment

Back-translation: seven commandment

IPA-transcription: /hæft dæstu:r/

Transliteration: seven order

Back-translation: Seven Order

Since is the title of the commandments, if it is distorted and manipulated, it will have a major impact on the target readership's mind in contemplating and discovering the core concept of the commandments. In TT2, "Commandment"

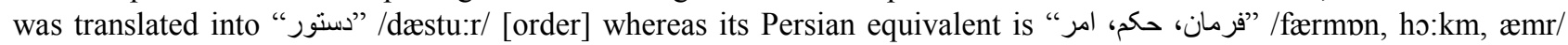
(Millennium Dictionary, 2005). It is noticeable that the meaning components of the original and translation do not match each other. In other words, the meaning of the word "commandment" which is given by someone in the highest position of authority was downgraded significantly in the translation. In fact, the power relations were heavily distorted.

Commandment 1 and 2.

ST: Whatever goes upon two legs is an enemy. TT1 : هر جه كه به روى دو با ر اه مى رود، دشمن است. 
IPA-transcription: /hær feh keh be ru:jeh do: pp ra:h mi:rævæd, do:fmæn æst/

Transliteration: whatever which upon two leg goes, enemy is

Back-translation: Whatever goes upon two legs is an enemy.

$$
\text { TT2 هر موجودى كه روى دو با راه مى رود، دشمن است. }
$$

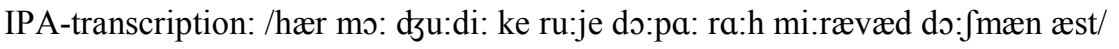

Transliteration: every creature which upon two leg goes, enemy is

Back-translation: Every creature which goes upon two legs is an enemy.

\section{ST: Whatever goes upon four legs, or has wings, is a friend.}

$$
\text { TT1 هر جه كه به روى جهار پا راه مي رود، يا بال دارد، دوست است. }
$$

IPA-transcription: /hær teh keh be ru:jeh tfphpr pv ra:h mi:rævæd, jp ba:l da:ræd, du:st æst/

Transliteration: whatever which upon four leg goes, or wing has, friend is

Back-translation: Whatever goes upon four legs, or has wing, is a friend.

$$
\text { TT2 هر موجودى كه روى جهار پِا راه مى رود، دوست است. }
$$

IPA-transcription: /hær mo:d孔u:di: ke ru:je t a:ha:r pa: ra:h mi:rævæd, du:st æst/

Transliteration: every creature which upon four leg goes, friend is

Back-translation: Every creature which goes upon four legs, is a friend.

In the first and second commandment in TT2, regarding lexical variation, the expression "هر موجودى كه " /hær mo:dzu:di: $\mathrm{ke} /[$ every creature which] is not a proper equivalent of whatever. This was the same problem in the first commandment

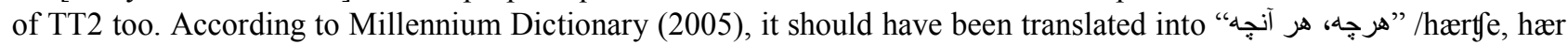
unte/. The expression "or has wings", that is the birds, was deliberately omitted and suppressed in the translation. Although the source text author added the detail information about birds and included them in the circle of animals emphasizing on solidarity, they were excluded in the translation. In fact, Orwell refers to the birds as pigeonmessengers with the belief that "the revolution should be encouraged in other countries, leading to an international Revolution of the proletariat" by enlisting "the birds to spread news of the Rebellion to farms across England. Thus, Animal Farm is not just an example of change but an agent of the new solidarity of the animals" (Gradesaver. Retrieved 27/7/2013). This very significant ideological concept was missed in the translation.

Commandment 3.

\section{ST: No animal shall wear clothes.}

IPA-transcription: /hi:ty hejva:ni: leba:s bær tæn næxa:hæd kærd/

Transliteration: no animal clothes on body will not put on

Back-translation: No animal will put on clothes.

IPA-transcription: /hi:t hejva:ni: leba:s nemi:pu:〔æd/

Transliteration: no animal clothes does not wear

Back-translation: No animal wears clothes.

Discoursally, to wear clothes is one of the man's evil habits since clothes denotes hypocrisy. However, in the third commandment in TT1, the verb "بر تن كردن" /bær tæn kærdæn/ [put on] is not an accurate Persian equivalent of the verb wear since their meaning components do not match to the full. This is a case of lexical variation. Orwell embedded some very ideological concepts in this term. Wear consists of the concepts as follows (Merriam-Webster, n.d.):

(a) To accept or tolerate without complaint: Orwell highlighted that the animals should not tolerate the oppressive human's tyranny against them. They should not be tight-lipped and reticent about the events around themselves but be the first to complain loudly about the unacceptable and unsatisfactory situation. Thus, if they accept the situation it will be the death of all their hopes.

(b) To grow or become by attrition or use: This means that human exploits the animals by making them work to the death. It can be claimed that since the animals worked hard from dawn to dusk, they would not have the opportunity to contemplate any objections or opposition or rebellion but accept the pigs' ideas and statements.

(c) To diminish or fail with the passage of time: This demonstrates that the animals will gradually lose their power and be oppressed. Thus, they will be deliberately made appear less important or valuable than they really are. Consequently, their genuine identity is lost without question.

(d) To hold the rank or dignity or position signified by (an ornament): Since Orwell was "a British political novelist and essayist with pointed criticisms of political oppression and totalitarianism" (Khorsand \& Salmani, 2014a, p. 232), in his novel Animal Farm, he expressed his great deal of opposition to discrimination of all types, racism, injustice and inequality.

On the other hand, the modal verb "shall" refers to "an order, law, promise etc." (LDOCE, 2009). In other words, "shall" is "used in laws, regulations, or directives to express what is mandatory" and "to give a command or to say that 
you will or will not allow something to happen" (Merriam-Webster, n.d.). The Persian equivalent of is "shall” is "بايد" /ba:jæd/ or "بايستى"/ba:jesti:/ [must] (Millennium Dictionary, 2005). Since this sentence is one of the seven commandments, the concept of order [emphasis added] was ideologically manipulated and distorted in the translation by being neutralized. That is, whereas the original text stresses on the compulsory action, the translation emphasizes the optional action. In the third commandment in TT2, similar to the discussion of TT1 and in relation to lexical variation " نمى بوشد " into /nemi:pu:\{æd/ [does not wear]. Whereas the original is an order/rule, the translation highlights that not to wear is a fact and a habit among the animals.

Commandment 4.

\section{ST: No animal shall sleep in a bed.}

IPA-transcription: /hi:t hejva:ni: dær bæstær næxa:hæd xa:bi:d/ TT1 :Tيج حيو انى در بستر نخو اهد خو ابيد.

Transliteration: no animal in bed will not sleep

Back-translation: No animal will sleep in bed.

IPA-transcription: /hi:t hejva:ni: ru:je tæxt nemi:xa:bæd/

TT2 : هيج حيو انى روى تخت نمى خو ابد.

Transliteration: no animal on bed does not sleep

Back-translation: No animal sleeps in bed.

The fourth commandment indicates that all animals should be in equal life conditions. From a different perspective, this commandment underlines that the animals should not be free even for a while but always have a hectic working schedule. In other words, if the animals sleep in beds, they will be in repose and their expectations will grow with inquisitiveness.

Similar to the discussion of the third commandment, in TT1, "no . . . shall sleep" should have been translated into $\theta /{ }^{\prime \prime}$ ÖLðZ /næba:jæd bexa:bæd/ [must/shall not sleep]. This is the same problem in TT2 too. This is a case of an immense ideological distortion. On the other hand, since Animal Farm is a novel for the contemporary readers, the archaic word “بتر" /bæstær/ [(archaic) bed] is not a strictly accurate Persian equivalent of "bed" (Dehkhoda, 1998/2013). Therefore, the readership effect would be different in the original and translation.

Commandment 5 .

\section{ST: No animal shall drink alcohol.}

IPA-transcription: /hi:tf hejva:ni: mæfru:ba:t e ælks:li: næxa:hæd nu:fi:d/

$$
\text { :TT1 هيجج حيو انى مشروبات الكلى نخو اهد نوشيد. }
$$

Transliteration: no animal drinks alcohol will not drink

Back-translation: No animal will drink alcohol.

IPA-transcription: /hi:t hejva:ni: nu:fi:dæni: nemi:nu: $æ 2 d /$

Transliteration: no animal a beverage does not drink

Back-translation: No animal drinks beverages.

In the fifth commandment in TT1, the verb "no . . . shall drink" should have been translated into । "

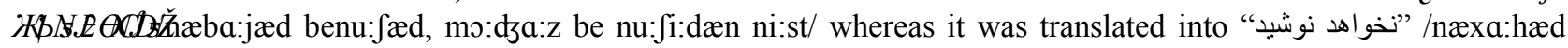
nu: $\int \mathrm{i}: \mathrm{d} /$ [will not drink]. Moreover, the mechanisms applied to TT2 include distorted lexical item, under-lexicalization, euphemism, and modalization. The expression "alcohol" which refers to "drinks such as beer, wine, etc. that can make people drunk" (OUP, n.d.) was simply translated into the noun "نوشيدنى"/nu:fi:dæni:/ [drink]. That is, the translator has unnecessarily used euphemism as the strategy for this immense ideological distortion by applying a culture filter. The translation does not include all of the meaning components of "alcohol". In other words, the translation indicates that no animal drinks anything even water. In contrast, the original text stresses the evilness of alcoholic drinks which avoid human beings and animals in this novel from thinking logically. This ideological concept was deliberately missed in the translation.

Commandment 6.

\section{ST: No animal shall kill any other animal.}

IPA-transcription: /hi:tt hejva:ni: hejva:n e di:gæri: ra: næxa:hæd ko:ft/

Transliteration: no animal, animal other will not kill

Transliteration: No animal will kill other animals.

$$
\text { هيج حيوانى، حيو ان ديكرى را نخو اهد كثت. :TT1 }
$$


IPA-transcription: /hi:t hejva:ni: hejva:n e di:gæri: ra: nemi:ko:〔æd/

Transliteration: no animal animal other does not kill

Back-translation: No animal kills other animals.

In the sixth commandment in TT1, the verb "no . . . s shall kill” should have been translated into نشبايد بكد/næba:jæd

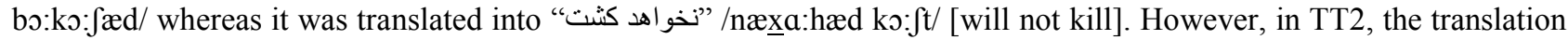
indicates a fact in which murder of animals is absent among them whereas the original denotes an order or rule. On the other hand, if it is a fact why it is a commandment! In fact, the original maintains the representation of morality. That is, killing or murder is evil [emphasis added]. This ideological concept was heavily distorted in the second translation.

Commandment 7.

\section{ST: All animals are equal.}

IPA-transcription: /hæmeh je hejva:na:t bæra:bærænd/

$$
\text { TT1/2 }
$$

Transliteration: all animals equal are

Transliteration: All animals are equal.

Surprisingly, the last commandment was translated exactly the same in both translations. No modification or distortion is observed in this expression.

Note. Although all the commandments were distorted in action throughout the novel, the commandments 4, 5, 6, and 7 were the ones distorted in words with some modifications.

Distorted Commandment 4.

ST: No animal shall sleep in a bed with sheets. (p. 38)

] [Not translated: [ترجمه نشده است :TT1

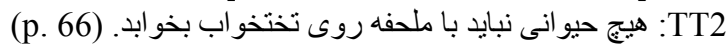

IPA-transcription: /hi:t hejva:ni: næba:jæd ba: mælhæfe ru:je tæxt bexa:bæd/

Transliteration: no animal shall not with sheet on bed sleep

Back-translation: No animal shall sleep in a bed with sheets.

The modified fourth commandment was not translated in TT1. This can be considered as a significant ideological distortion in the translation. Whereas Orwell tried to foreground the pigs' manipulation of the original commandment and their sense of hypocrisy and dishonesty, this has been removed from the translation. However, TT2 was highly

successful in transmitting the message from the source text.

Distorted Commandment 5.

ST: No animal shall drink alcohol to excess. (p. 54)

(p. 104) هيج حيو انى به حد افر اط مشروبات الكلى نمى نوشد. :TT1

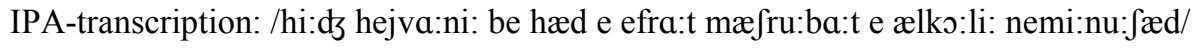

Transliteration: no animal to excess alcohol alcoholic does not drink

Back-translation: No animal drinks alcohol to excess.

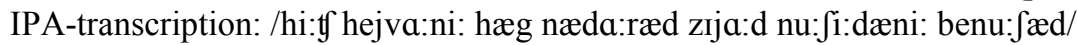

(p. 101) هيج حيو انى حق ندارد زياد نوشيدنى بنوشد. TT2

Transliteration: no animal right does not have much drink drinks

Back-translation: No animal has the right to drink beverages.

TT1 is a neutral sentence indicating that not drinking alcoholic beverages by animals is a fact. TT2, on the other hand, did not indicate anything about the alcohol. In fact, TT2 implies that the animals do not have the right to drink any kinds of beverages, neither alcoholic nor non-alcoholic.

Distorted Commandment 6.

ST. No animal shall kill any other animal without cause. (p. 46)

(p. 89) هيج حيو انى بدون علت حيو ان ديكرى را نمى كثند: :TT1

IPA-transcription: /hi:t hejva:ni: bedu:ne el ' læt hejva:ne di:gæri: ra: nemi:ko:fæd/

Transliteration: no animal without cause animal another does not kill

Back-translation: No animal kills another animal without cause. 
IPA-transcription: /hi:ty hejva:ni: næba:jæd hejva:ne di:gæri: ra: bi:dæli:1 boksæd (p5)

Transliteration: no animal shall not animal another without cause kills

Back-translation: No animal shall kill another animal without cause.

TT2 transmitted the message from the original to the translation successfully. However, TT1 carried out a significant distortion indicating that not killing the animals by themselves without cause is a fact where it is not. From critical discourse analysis point of view, TT1 illuminates that killing the fellow animals with cause is legitimate. It can be claimed that the expression "without cause" is only in justification of murder.

Distorted Commandment 7.

ST: All animals are equal. BUT SOME ANIMALS ARE MORE EQUAL THAN OTHERS. (p. 63)

(p. 125) همه حيو انات بر ابرند اما بعضى از حيو انات از ديكر حيو انات بر ابرى بيشترى دارند :TT1

IPA-transcription: /hæmeje hejva:na:t bæra:bærænd æm' ma: bæ'zi: æz hejva:na:t æz di:gære hejva:na:t bæbæri:je bi:ftæri: da:rænd/

Transliteration: all animals equal are but some of animals of other animals equality more have

Back-translation: All animals are equal but some animals are of more equality than others.

(p. 123) :TT2 : همه حيو انات بر ابرند اما بعضى از حيوانات برنرند.

IPA-transcription: /hæmeje hejva:na:t bæra:bærænd æm 'ma: bæ'zi: æz hejva:na:t bærtærænd/

Transliteration: all animals equal are but some of animals surpass

Back-translation: All animals are equal but some animals surpass [the others].

TT2 transmitted the message from the original to a greater extent than TT1. On the other hand, in TT1, there is a case of dubious acceptability. In other words, the content of this sentence is not acceptable to Persian readers.

\subsection{The Results}

Regarding the mechanisms including lexicalization and dominant syntactic metaphors discussed in the in-depth analysis of the texts, Table 1 illuminates the rate of lexicalization mechanisms in both translations.

Table 1. Lexicalization Mechanisms in TT1 and TT2

\begin{tabular}{lll}
\hline Lexicalization Mechanisms & TT1 & TT2 \\
\hline Distorted lexical item & 0 & 1 \\
Lexical variation & 2 & 3 \\
Over-lexicalization & 2 & 0 \\
Under-lexicalization & 0 & 1 \\
Euphemism & 0 & 2 \\
Addition & 0 & 0 \\
Omission & 1 & 1 \\
\hline
\end{tabular}

Based on Table 1, the highest rate of distortions in lexicalization mechanisms carried out in the subcategory of lexical variation particularly in TT2. It can be claimed that lexical variation and over-lexicalization in TT1 were the main focus of manipulation of the translators regarding lexicalization mechanisms. However, Table 2 highlights the rate of dominant syntactic metaphors in the translations.

Table 2. Mechanisms of Dominant Syntactic Metaphors in TT1 and TT2

\begin{tabular}{lll}
\hline Syntactic Mechanisms & TT1 & TT2 \\
\hline Transitivity & 0 & 0 \\
Nominalization & 0 & 0 \\
Modalization & 4 & 4 \\
\hline
\end{tabular}

Based on Table 2 and regarding the mechanisms of dominant syntactic metaphors in TT1 and TT2, the very subcategory of modalization was manipulated by both of the translators at the same rate. However, Table 3 shows the total mechanisms including lexicalization and dominant syntactic metaphors in the two translations.

Table 3. Total Mechanisms of TT1 and TT2

\begin{tabular}{lll}
\hline Mechanisms & TT1 & TT2 \\
\hline Lexicalization Mechanisms & 5 & 8 \\
Syntactic Mechanisms & 4 & 4 \\
Total Mechanisms & 9 & 12 \\
\hline
\end{tabular}


According to Table 3, the total errors observed in TT2 are significantly more than TT1. In other words, lexicalization mechanisms in TT2 took the higher rate of manipulation among the other mechanisms. However, there is an equality between TT1 and TT2 in the rate of manipulation of syntactic mechanisms.

\section{Conclusions}

The main purpose of this paper was the quality assessment of two Persian translations of the excerpt "The Seven Commandment" from Orwell's Animal Farm under the CDA framework of Van Dijk and Lefevere's notion of ideology, change and power in literature and society. In this study, CDA gave us a comprehensive insight into the discursive structures of literary translated texts. Hence, CDA was used as a methodological and analytical tool for pinpointing the ideological manipulation in the political literary discourse. In fact, CDA offered a framework which uncovered the ideological content as well as the ways in which ideology was expressed, reinforced, and observed in the Persian translations. Focusing on the ideologies and power relations behind any lexical and grammatical choices in the source and target texts and considering the results, we explored and discovered the manipulation of the original ideologies and power relations through the discursive structures in the Persian translations. In other words, the analysis proved that certain lexical and grammatical items were added, omitted, and distorted, which points to the fact that the original sociopolitical ideology was dramatically manipulated in the translations. In fact, significant distortions and ideological manipulation in both translations were observed. The total errors discovered in the translations demonstrated in Table 3. However, the rate of the distortions and manipulation was immense in TT2 particularly in the realm of lexicalization mechanisms regarding cultural issues. In addition, the distortions and manipulation of the original in the translations were arbitrary and ideological. Accordingly, the social effect the source text readership achieves would be radically different from that of the target text. The manipulation of the original ideologies through the novel is the manifestation of a totalitarian system established by the pigs in Animal Farm. In such a system the animals as ordinary people have no power and are completely controlled by the pigs. On the other hand, the original ideologies manipulated in the translation indicates that special ideologies were embedded in the Persian translations of the seven commandments as well. Therefore, based on the CDA framework of Van Dijk (1999) under Lefevere's (2002) notion of ideology, change and power in literature and society, particular sociocultural, sociopolitical and ideological constraints under which the translations were done affect the translations of this literary discourse. Furthermore, it can be proved that although both Persian translations were not translated adequately, TT2 is considered more inadequate than TT1 on account of more manipulation and distortions of the original ideology and power relations.

It should be underlined that although some of the original commandments were not manipulated officially in words, they were distorted in practice. This distortion is clearly tangible through the novel. For example, at the end of the novel, the pigs begin to walk on two legs like humans. This is breaking the first two commandments in which an enemy from a friend was differentiated. The third commandment is violated when the pigs eventually start to dress in clothing. The other commandments are broken through the novel with some modifications. In general, the manipulation of the seven commandments was all for the benefit of the pigs as the main responsible leaders of the animals. In fact, the logic behind the changes was for gaining the full benefit of the situation and their official position. Providing themselves with an unrivaled position of power, trust and influence, the pigs' aims were to maintain and abuse their position and the system they made by themselves. In other words, the pigs abused the animals as a tool for improving their own and not the animals' welfare benefits. This led the pigs to have special privilege which deepened the social-class discrimination. This was sheer inequity and injustice resulting in different types of impoverishment. The term "privilege" in this context means "the rights and advantages that rich and powerful people in a society have" (OUP, n.d.). As a member of the nobility, Napoleon's life had been one of wealth and privilege. We can claim that the seven commandments are the Constitution of Animal Farm which by the total manipulation called the animals' equal rights into question and even the animals' simple rights were diminished and ignored. Thus, the seven commandments, specially the modified and manipulated ones, can be considered as propaganda (see Khorsand \& Salmani, 2014a). These sociopolitical notions should be considered in the process of translation.

Furthermore, it can be claimed that literary texts have always been the facilitators and in some cases the origin of evolutionary and even revolutionary social changes and turning points. Literary texts inspire the human mind with intellectual insights and enforce the man to contemplate resolving social problems. Thus, through a qualitatively comparative, contrastive and analytical approach, critical discourse analysis (CDA) provides translation students, translators and researchers in the field of translation studies (TS) with meticulously comprehensive viewpoints on literary texts and their translations. These viewpoints assist them in disclosing original and translation texts' embedded linguistic and extra-linguistic aspects such as (manipulation of) ideology, power relations, and sociocultural and historical backgrounds. In other words, the findings of the present study and/or other CDA-oriented researches aim to contribute to a better understanding and thoughtful analysis of literary texts and their translations. Moreover, it should not be taken for granted that the very essential (and often invisible) tool for making every text unbiased, innocent or neutral is the ideological filter. Thus translators' scrupulous socio-discoursal awareness and consciousness of every discursive strategy or choice play a significant role in the process of translating. This awareness should be taken into account in the ideologies embedded in wider social practices of power and authority.

It is claimed that authors of literary texts construct and embed special ideologies in their works that create special (social) images in the readers' minds. Regarding literary translations, the more manipulation of original ideologies, different images will be created in the target readers' minds. Therefore the response and feedback that are received from the source and target readerships would be totally different. This will lead to different sociopolitical outcomes. Thus the 
present research opens the eyes of translators and literary translation researchers to the special significance of social factors and communicative effectiveness. In other words, professional readers, translators and literary translation researchers need to keep their eyes open when reading, translating, comparing, contrasting, and analyzing literary texts to find out more about social factors and communicative effectiveness.

\section{References}

Cameron, D. (2007). The Teacher's Guide to Grammar. UK: Oxford University Press.

Dehkhoda, A. (1998/2013). Dehkhoda Dictionary. Retrieved 2013, from www.vajehyab.com

Eagleton, T. (1991). Ideology: An Introduction. London and New York: Verso.

Fairclough, N. (1992). Discourse and Social Change. Cambridge: Polity Press.

Fairclough, N. (2001a). How to Analyze Talk in Institutional Settings. In A. McHoul, \& M. Rapley, Critical Discourse Analysis (pp. 25-41). London: Continuum.

Fairclough, N. (2001b). Language and Power. London: Pearson Education.

Fowler, R. (1991). Linguistic Criticism. Oxford: Oxford University Press (OUP).

Gradesaver Editors (Ed.). (2013). Animal Farm Study Guide \& Literature Essays. Retrieved 7 27, 2013, from

http://www.gradesaver.com/animal-farm/.

Haghshenas, A., Samei, H., \& Entekhabi, N. (2005). Hezareh or Millennium Dictionary. Tehran: Farhang Moaser

Publisher.

Heydari Manjili, N. (2009). Mazraeye Heyvanat [The Farm of Animals]. Tehran: Ordibehesh Publisher.

Hitchings, H. (2013, April 5). The Dark Side of Verbs-as-Nouns. Retrieved July 27, 2013, from The New York Times:

http://opinionator.blogs.nytimes.com/2013/04/05/the-dark-side-of-verbs-as-nouns/

Khorsand, M., \& Salmani, B. (2014a). Anthems as Propaganda: A Discoursal Translation Quality Assessment.

International Journal of Language Learning and Applied Linguistics World (IJLLALW), 5(3), 222-237. Retrieved from http://www.ijllalw.org/finalversion5319.pdf

Khorsand, M., \& Salmani, B. (2014b). Manipulation of Original Ideology Through Translation: A Discourse-Based

Translation Quality Assessment of Speeches. International Journal of Applied Linguistics and English Literature

(IJALEL), 3(5), 134-149. Retrieved from http://dx.doi.org/10.7575/aiac.ijalel.v.3n.5p.134

Lefevere, A. (1992). Translation, Rewriting, and the Manipulation of Literary Fame. London and New York:

Routledge.

Lefevere, A. (Ed.). (2002). Translation/History/Culture: A Sourcebook. Chicago: Routledge.

Longman, P. (2009). Longman Dictionary of Contemporary English (LDOCE) (3rd ed.). UK: Pearson Education.

Mayr, A. (2008). Language and Power: An Introduction to Institutional Discourse. London and New York: Continuum International Publishing Group.

Merriam-Webster. (n.d.). Retrieved July 2014, from Merriam-Webster's Collegiate Dictionary: http://www.merriamwebster.com/dictionary/

Noor-Ahmar, N. (1983). Mazraeye Heyvanat [The Farm of Animals]. Tehran: Marzban Publisher.

Nord, C. (1991). Text Analysis in Translation: Theory, Methodology, and Didactic Application of a Model for

Translation-oriented Text Analysis. Amsterdam: Rodopi.

Nord, C. (2003). Function and Loyalty in Bible Translation. In M. Calzada-Pérez, Apropos of Ideology (pp. 89-112).

Philadelphia: Multilingual Matters.

Orwell, G. (1945/1976). George Orwell: Animal Farm, Burmese Days, A Clergyman's Daughter, Coming Up for Air,

Keep the Aspidistra Flying, Nineteen Eighty-Four: Complete \& Unabridged. Great Britain: Secker and Warburg :

Octopus Books.

Oxford University Press (OUP) . (n.d.). Oxford Advanced Learner's Dictionaries. (Author) Retrieved July 2014, from

http://www.oxfordlearnersdictionaries.com/

Palmer, F. (2001). Mood and Modality (2nd ed.). Cambridge, England: Cambridge University Press.

Plamentaz, J. (1970). Ideology. London: Pall Mall.

Richards, J. C., \& Schmidt, R. W. (2002). Longman Dictionary of Language Teaching and Applied Linguistics (3rd ed.). UK: Longman.

Schäffner, C. (2003). Third Ways and New Centers: Ideological Unity or Difference? In M. Calzada-Pérez, Apropos of Ideology (pp. 23-42). Philadelphia: Multilingual Matters.

SparkNotes Editors (Ed.). (2007). SparkNote on Animal Farm. Retrieved 12 13, 2012, from SparkNote:

http://www.sparknotes.com/lit/animalfarm/

Van Dijk, T. (1996). Discourse, Opinions and Ideologies. In C. Schäffner, \& H. Kelly-Holmes, Discourse and

Ideologies (pp. 7-37). Philadelphia: Multilingual Matters.

Van Dijk, T. (1998). Ideology: A Multidisciplinary Approach. California: Sage.

Van Dijk, T. (1999, October). Critical Discourse Analysis and Conversation Analysis. Discourse \& Society, 10(4), 459460. doi:10.1177/0957926599010004001

Van Dijk, T. (2000). Ideology and Discourse. A Multidisciplinary Introduction. An Internet Course for the Universitat Oberta de Catalunya (Open University). Barcelona: Pompeu Fabra University. Retrieved from

http://discourses.org/download/books/

Wilde, O. (n.d.). http://quotes.lifehack.org/quote/oscar-wilde/true-friends-stab-you-in-the-front/. Retrieved May 2014, from http://quotes.lifehack.org/. 